\title{
Implementasi Pembelajaran Tematik Di Raudhotul Athfal Al-Muslimun Kota Palangka Raya
}

\author{
Sri Hidayati', Muzakki2, Asmail Azmy ${ }^{3}$ \\ 1IAIN Palangka Raya, Kota Palangka Raya, Indonesia, Email: \\ sasasrihidayati@yahoo.co.id \\ 2IAIN Palangka Raya, Kota Palangka Raya, Indonesia, Email:muzakki@iain- \\ palangkaraya.ac.id \\ 3IAIN Palangka Raya, Kota Palangka Raya, Indonesia
}

\begin{abstract}
ABSTRAK
Kurikulum 2013 Pendidikan Anak Usia Dini menggunakan pembelajaran tematik. Pembelajaran tematik dipandang sesuai dengan pola kerja otak karena membahas satu tema dari berbagai konsep dan aspek perkembangan. Penelitian ini bertujuan: 1). Mendiskripsikan perencanaan pembelajaran tematik di RA AlMuslimun kota Palangka Raya; 2). Mendiskripsikan pelaksanaan pembelajaran tematik di RA Al-Muslimun kota Palangka Raya, dan 3). Mendiskripsikan penilaian pembelajaran tematik di RA Al-Muslimun kota Palangka Raya. Metode yang digunakan dalam penelitian implementasi pembelajaran tematik di RA AlMuslimun ini adalah penelitian kualitatif dengan pendekatan studi kasus. Hasil penelitian ini: 1) Perencanaan pembelajaran tematik di RA Al Muslimun dimulai dengan penentuan tema yang dilakukan oleh semua guru di awal tahun pelajaran untuk menentukan tema-tema yang dipilih untuk satu tahun. Tema yang dipilih dibuat ke dalam RPPM dan kemudian dituangkan ke dalam RPPH; dan 2) Pelaksanaan pembelajaran tematik di RA Al-Muslimun sesuai dengan prinsipprinsip pembelajaran tematik yaitu kedekatan tema dengan kehidupan anak, kesederhanaan tema bagi anak, kemenarikan tema bagi anak, serta tema insidental dalam pembelajaran. Setiap tema diakhiri dengan melaksanakan kegiatan puncak tema. Penilaian pembelajaran tematik di RA Al-Muslimun menggunakan penilaian percakapan, penugasan project, dan hasil karya anak. Kata Kunci: Implementasi, Pembelajaran Tematik, Pendidikan Anak Usia Dini
\end{abstract}

\section{ABSTRACT}

2013 Curriculum Early Childhood Education uses thematic learning. Thematic learning is seen in accordance with the working pattern of the brain because it addresses one theme from various concepts and aspects of development. This research was intended to: 1) Describe thematic learning planning at RA AlMuslimun, Palangka Raya city; 2) Describe the implementation of thematic learning at RA A1-Muslimun, Palangka Raya city, and 3). Describe the assessment of thematic learning in RA Al-Muslimun, Palangka Raya city. The method used in this research was qualitative research with a case study approach. The results of this research were: 1) Thematic learning planning in RA Al Muslimun with the determination of the theme carried out by all teachers at the beginning of the school year to determine the themes chosen for one year. The chosen theme was made into RPPM and then made into RPPH; and 2) The implementation of thematic 
learning in RA Al-Muslimun was in accordance with the thematic learning principles, namely the closeness of the theme to children's lives, the simplicity of themes for children, the attractiveness of themes for children, and incidental themes in learning. Each theme was ended by carrying out peak activities theme. The thematic learning assessment at RA Al-Muslimun used conversation assessment, project assessment, and children's work.

Keywords: Implementation, Thematic Learning, Early Childhood Education

Article history:

Received : 03-12-2018

Revised : 07-02-2019

Accepted : 08-02-2019

\section{PENDAHULUAN}

Pendidikan Anak Usia Dini (PAUD) merupakan pendidikan fundamental karena perkembangan anak di masa selanjutnya dipengaruhi oleh stimulasi tumbuh kembang yang diberikan sejak usia dini. Awal kehidupan anak merupakan masa yang paling tepat dalam memberikan dorongan atau upaya pengembangan agar anak dapat berkembang secara optimal.

Kurikulum 2013 Pendidikan Anak Usia Dini (K-13 PAUD) mencakup pengembangan pada aspek struktur kurikulum, proses pembelajaran dengan pendekatan saintifik, dan penilaian yang bersifat autentik. (K-13 PAUD) mengusung pengembangan pembelajaran konstruktivisme yang lebih bersifat fleksibel dalam pelaksanaan sehingga memberi ruang pada anak untuk mengembangkan potensi dan bakatnya. (K-13 PAUD) dalam proses pelaksanaannya menggunakan pembelajaran tematik (Mustofa, 2015: 1) Pembelajaran tematik dipandang sesuai dengan pola kerja otak karena membahas satu tema dari berbagai konsep dan aspek perkembangan. Penentuan tema dalam (K-13 PAUD) sangat terbuka. Artinya, satuan PAUD dapat menentukan tema yang akan digunakan dalam pembelajaran sesuai dengan minat anak, situasi dan kondisi lingkungan, serta kesiapan pendidik mengelola kegiatan. Penentuan tema tidak sekadar mudah diterapkan, tetapi perlu memperhatikan beberapa prinsip agar pembelajaran yang dilaksanakan lebih menarik dan mendalam. Keluasan tema bergantung pada kemampuan pendidik dalam menguasai tema tersebut. Hal penting yang harus diperhatikan pendidik dalam mengembangkan tema adalah 
kebermaknaan tema dalam

emosi atau minat anak. membangun pengalaman belajar yang bermutu bagi anak usia. Oleh karena itu dalam menentukan tema menjadi penting bila diawali dengan identifikasi tema dan sekaligus ketertarikan anak terhadap topik tertentu.

Hasil observasi di lapangan menunjukkan bahwa pembelajaran tematik telah dilaksanakan oleh RA Al-Muslimun Kota Palangka Raya. Dalam pelaksanaan pembelajaran tematik yang digunakan mengambil dari panduan yang dibuat oleh IGRA (Ikatan Pendidik Raudhotul Athfal) Kota Palangka Raya. Sehingga dalam penggunaan tema-tema pembelajaran pendidik dan anak menyesuaikan dengan tema yang sudah ada. Sedangkan dalam membuat tema-tema pembelajaran ada beberapa prinsip pembelajaran tematik yang harus dilakukan. Prinsip tersebut yaitu kedekatan, kesederhanaan, kemenarikan, dan keinsidentalan tema yang digunakan dalam pembelajaran (Mustofa, 2015: 2). Kedekatan, artinya tema hendaknya dipilih mulai dari hal-hal yang terdekat dengan kehidupan anak. Dekat dimaksud dapat dekat secara fisik dan juga dekat secara

Kesederhanaan, artinya tema yang dipilih yang sudah dikenal anak agar anak mudah memahami pokok bahasan dan dapat menggali lebih banyak

pengalamannya.

Kemenarikan, artinya tema yang dipilih harus menarik bagi anak dan mampu menarik minat belajar anak. Keinsidentalan, artinya pemilihan tema tidak selalu yang direncanakan di awal tahun, dapat juga menyisipkan kejadian luar biasa yang dialami anak, misalnya peristiwa banjir yang dialami anak dapat dijadikan tema insidental menggantikan tema yang sudah direncanakan sebelumnya.

\section{METODE PENELITIAN}

Metode yang digunakan dalam penelitian ini adalah penelitian kualitatif dengan pendekatan studi kasus. Penelitian kualitatif adalah penelitian yang menghasilkan data deskriptif berupa kata-kata tertulis atau lisan dari orang dan perilaku yang diamati (Moeleong, 2004 :3). Pendekatan studi kasus dalam penelitian ini yaitu : penelitian dilaksanakan pada suatu unit sosial lembaga atau single-case study (studi kasus tunggal) yaitu pada 
lembaga RA Al-Muslimun. Alasan dipilihnya lembaga PAUD RA AlMuslimun sebagai tempat lokasi penelitian karena proses pembelajaran di lembaga tersebut telah menerapkan pembelajaran tematik dan dijadikan percontohan bagi lembaga RA lainnya di Kota Palangka Raya. Tempat penelitian dilaksanakan di lembaga RA AlMuslimun yang beralamat di $\mathrm{Jl}$. Ahmad Yani Komplek Masjid Raya Nurul Islam Kota Palangka Raya.

Subjek dari penelitian ini yaitu pengelola, pendidik, dan peserta didik yang ada di lembaga PAUD RA Al-Muslimun kota Palangka Raya. Adapun karakteristik dari subjek atau responden sebagai berikut :

1. Pengelola yaitu PAUD RA AlMuslimun untuk mengetahui alasan dan manajemen implementasi pembelajaran tematik.

2. Pendidik yaitu orang yang melakukan proses pembelajaran tematik, dari pendidik di ketahui bagaimana perencanaan, pelaksanaan dan evaluasi pembelajaran tematik.

3. Peserta didik yaitu anak usia dini yang berada di RA Al-Muslimun yang sudah mengikuti

\section{HASIL DAN DISKUSI}

\section{A. Perencanaan Pembelajaran Tematik di RA Al-Muslimun}

Langkah-langkah perencanaan pembelajaran tematik di RA AlMuslimun berdasarkan hasil wawancara dengan kepala RA dan pendidik yaitu :

1. Identifikasi kebutuhan anak

Sebelum pelaksanaan pembelajaran tematik di RA AlMusimun Kota Palangka Raya terlebih dahulu kepala RA dan pendidik mengidentifikasi yang menjadi kebutuhan anak selama proses pembelajaran. Identifikasi yang dilakukan antara lain terkait dengan media pembelajaran, sarana dan prasarana serta hal-hal lain yang terkait dengan proses pembelajaran tematik di RA.

2. Menentukan tema dan alokasi waktu yang akan digunakan selama satu tahun.

Penentuan tema dilaksanakan dalam agenda pertemuan awal tahun pelajaran yang dikuti oleh 
semua pendidik dan kepala RA. Hasil dari pertemuan ini menentukan tema yang akan digunakan selama satu tahun. Tema yang sudah ditentukan kemudian di buat oleh pendidik dalam program tahunan. Adapun program tahunan yang sudah dibuat sebagai berikut :

Tabel 1. Tema Tahunan RA Al Muslimun

\begin{tabular}{|c|c|c|}
\hline No. & Tema & $\begin{array}{l}\text { Alokasi } \\
\text { Waktu }\end{array}$ \\
\hline 1. & $\begin{array}{l}\text { Aku Hamba } \\
\text { Allah }\end{array}$ & 3 Minggu \\
\hline 2. & Tanah Airku & 2 Minggu \\
\hline 3. & $\begin{array}{l}\text { Keluarga } \\
\text { Sakinah }\end{array}$ & 3 Minggu \\
\hline 4. & Lingkunganku & 3 Minggu \\
\hline 5. & $\begin{array}{l}\text { Binatang } \\
\text { Ciptaan Allah }\end{array}$ & 3 Minggu \\
\hline 6. & $\begin{array}{l}\text { Tanaman } \\
\text { Ciptaan Allah }\end{array}$ & 3 Minggu \\
\hline 7. & $\begin{array}{l}\text { Rekreasi dan } \\
\text { Kendaraan }\end{array}$ & 4 Minggu \\
\hline 8. & Pekerjaan & 3 Minggu \\
\hline 9. & $\begin{array}{l}\text { Alat } \\
\text { Komunikasi }\end{array}$ & 2 Minggu \\
\hline 10. & $\begin{array}{l}\text { Air, Udara, } \\
\text { dan Api }\end{array}$ & 3 Minggu \\
\hline 11. & Alam Semesta & 3 Minggu \\
\hline 12. & $\begin{array}{l}\text { Amaliah } \\
\text { Ramadhan }\end{array}$ & 3 Minggu \\
\hline
\end{tabular}

3. Pendidik membuat program semester

Program semester yang dibuat memuat tentang tema, sub tema, dan alokasi waktu. Program semester yang dikembangkan mengacu pada program tahunan yang telah ditentukan. Tema yang ada dalam satu tahun di analisis sesuai dengan kebutuhan anak dianalisis untuk dipilah ke dalam program semester. Adapun program semester pada RA Al-Muslimun tahun pelajaran 2017/2018 yaitu :

Tabel 2. Program Semester 1 RA Al Muslimun

\begin{tabular}{|c|c|c|c|}
\hline No. & Tema & Sub Tema & $\begin{array}{l}\text { Alokasi } \\
\text { Waktu }\end{array}$ \\
\hline 1. & $\begin{array}{l}\text { Aku } \\
\text { Hamba } \\
\text { Allah }\end{array}$ & $\begin{array}{ll}\text { - } & \text { Identitask } \\
& \mathrm{u} \\
\text { - } & \text { Tubuhku } \\
\text { - } & \text { Kesukaan } \\
& \mathrm{ku} \\
\end{array}$ & $\begin{array}{l}3 \\
\text { Minggu }\end{array}$ \\
\hline 2. & $\begin{array}{l}\text { Tanah } \\
\text { Airku }\end{array}$ & - Negaraku & $\begin{array}{l}2 \\
\text { Minggu }\end{array}$ \\
\hline 3. & $\begin{array}{l}\text { Keluarga } \\
\text { Sakinah }\end{array}$ & $\begin{array}{ll}\text { - } & \text { Anggota } \\
\text { keluargak } \\
\text { u } \\
\text { - } & \text { Profesi } \\
\text { anggota } \\
\text { keluarga } \\
\text { - Tata } \\
\text { tertib } \\
\text { dalam } \\
\text { keluarga } \\
\end{array}$ & $\begin{array}{l}3 \\
\text { Minggu }\end{array}$ \\
\hline 4. & $\begin{array}{l}\text { Lingkun } \\
\text { ganku }\end{array}$ & $\begin{array}{ll}\text { - } & \text { Rumahku } \\
\text { - } & \text { Sekolahk } \\
& \mathrm{u} \\
\text { - } & \text { Masjidku }\end{array}$ & $\begin{array}{l}3 \\
\text { Minggu }\end{array}$ \\
\hline 5. & $\begin{array}{l}\text { Binatang } \\
\text { Ciptaan } \\
\text { Allah }\end{array}$ & $\begin{array}{ll}\text { - } & \text { Binatang } \\
\text { qurban } \\
\text { - } & \text { Binatang } \\
\text { peliharaa } \\
\mathrm{n} \\
\text { - } & \text { Binatang } \\
\text { serangga } \\
\text { - } \\
\text { Binatang } \\
\text { buas }\end{array}$ & $\begin{array}{l}3 \\
\text { Minggu }\end{array}$ \\
\hline 6. & $\begin{array}{l}\text { Tanama } \\
\mathrm{n} \\
\text { Ciptaan } \\
\text { Allah }\end{array}$ & $\begin{array}{ll}\text { - } & \text { Tanaman } \\
\text { buah dan } \\
\text { sayuran } \\
\text { - Tanaman } \\
\text { hias } \\
\text { Tanaman } \\
\text { obat- } \\
\text { obatan } \\
\text { dan ubi- } \\
\text { ubian }\end{array}$ & $\begin{array}{l}3 \\
\text { Minggu }\end{array}$ \\
\hline
\end{tabular}


Tabel 3. Program Semester 2 RA Al Muslimun

\begin{tabular}{|c|c|c|c|}
\hline $\begin{array}{l}\mathbf{N} \\
\mathbf{o}\end{array}$ & Tema & Sub Tema & $\begin{array}{l}\text { Alokasi } \\
\text { Waktu }\end{array}$ \\
\hline 1. & $\begin{array}{l}\text { Rekreasi } \\
\text { dan } \\
\text { Kendara } \\
\text { an }\end{array}$ & $\begin{array}{ll}\text { - } & \text { Rekreasi } \\
\text { - } & \text { Kendaraan }\end{array}$ & 4 Minggu \\
\hline 2. & $\begin{array}{l}\text { Pekerjaa } \\
\mathrm{n}\end{array}$ & $\begin{array}{ll}\text { - } & \text { Macam- } \\
\text { macam } \\
\text { pekerjaan } \\
\text { - } \quad \text { Tempat } \\
\text { kerja } \\
\text { - } \text { Perlengkap } \\
\text { an berkerja }\end{array}$ & 3 Minggu \\
\hline 3. & $\begin{array}{l}\text { Alat } \\
\text { Komuni } \\
\text { kasi }\end{array}$ & $\begin{array}{ll}\text { - } & \text { Macam- } \\
\text { macam } \\
\text { kegunaan, } \\
\text { - } \quad \text { Bentuk } \\
\text { fisik } \\
\text { - Cara } \\
\text { mengguna } \\
\text { kan alat } \\
\text { komunikas } \\
\text { i } \\
\end{array}$ & 2 Minggu \\
\hline 4. & $\begin{array}{l}\text { Air, } \\
\text { Udara } \\
\text { dan Api }\end{array}$ & $\begin{array}{l}\text { Kegunaan/ } \\
\text { manfaat, } \\
\text { bahaya, } \\
\text { asal dan } \\
\text { sifat } \\
\text { Kegunaan } \\
\text { air, udara } \\
\text { dan api } \\
\end{array}$ & 3 Minggu \\
\hline 5. & $\begin{array}{l}\text { Alam } \\
\text { Semesta }\end{array}$ & $\begin{array}{ll}\text { - } & \begin{array}{l}\text { Benda- } \\
\text { benda }\end{array} \\
\text { alam } \\
\text { Benda- } \\
\text { benda } \\
\text { langit } \\
\text { Gejala } \\
\text { alam } \\
\end{array}$ & 3 Minggu \\
\hline 6. & $\begin{array}{l}\text { Amaliah } \\
\text { Ramadh } \\
\text { an }\end{array}$ & $\begin{array}{l}\text { Niat puasa } \\
\text { dan } \\
\text { amalan- } \\
\text { amalan } \\
\text { bulan } \\
\text { ramadhan } \\
\text { Zakat } \\
\text { - Sholat ied } \\
\end{array}$ & 3 Minggu \\
\hline
\end{tabular}

4. Pendidik membuat rencana pelaksanaan pembelajaran mingguan

Rencana pelaksanaan pembelajaran mingguan dibuat oleh oleh pendidik dengan berdiskusi dengan pendidik pada level yang sama misal pendidik kelas A1 dengan kelas A2 dalam menentukan kegiatan dalam satu minggu yang di laksanakan anak. Contoh rencana pelaksanaan pembelajaran mingguan yang dilaksanakan di RA Al-Muslimun yaitu : tema "pekerjaan" sub tema "macammacam pekerjaan", dari sub tema inilah dikembangakan RPPM dalam satu minggu. Karena sub tema "macam-macam pekerjaan" maka dikembangkan RPPM sebagai berikut : hari senin sub-sub tema "pendidik idolaku”, hari selasa subsub tema "polisi yang tangguh", hari rabu sub-sub tema "dokter", hari kamis sub-sub tema "pilot", hari jum'at sub-sub tema "pedagang" dan hari sabtu sub-tema "masinis".

5. Pendidik membuat rencana pelaksanaan pembelajaran harian

Pembuatan rencana pelaksanaan pembelajaran harian di RA AlMuslimun dibuat oleh masing- 
masing pendidik sesuai dengan usia kelompok anak.

ruangan bertujuan untuk menstimulasi aktivitas fisik-motorik anak dan membuang energi negatif

\section{B. Pelaksanaan Pembelajaran}

\section{Tematik di RA Al-Muslimun}

Pelaksanaan pembelajaran tematik di RA Al-Muslimun dilaksanakan dari hari Senin-Sabtu dimulai dari pukul 07.00 WIB dan berakhir pukul 10.00 WIB. Langkahlangkah pembelajaran sebagai berikut :

\section{Penyambutan anak}

Penyambutan

anak dilaksanakan dari pukul 06.3007.00 WIB, kegiatan penyambutan dilakukan oleh dua pendidik secara bergantian sesuai jadwal yang telah ditentukan oleh lembaga PAUD. Pendidik yang bertugas sebagai petugas penyambutan bertugas menyambut anak kemudian mengarahkan anak agar memasuki kelas untuk menaruh tas dan melakukan kegiatan mengaji dengan pendidik yang ada di kelas masingmasing.

2. Kegiatan bermain di luar ruangan

Setelah anak selesai mengaji, kemudian pendidik mengarahkan anak-anak untuk keluar kelas mengikuti kegiatan bermain di luar ruangan. Kegiatan bermain di luar yang ada pada anak sehingga ketika pembelajaran anak sudah merasa tenang. Adapun jenis kegiatan bermain di luar ruangan yang dilakukan di RA Al-Muslimun antara lain anak bermain perosotan, anak bermain ayunan, anak bermain panjat tali dan terkadang juga diisi dengan kegiatan senam. Kegiatan bermain di luar ruangan dilaksanakan dari pukul 07. 0007.30 WIB.

3. Pembelajaran inti

Pembelajaran inti dilaksanakan setelah anak-anak bermain di luar rungan. Pembelajaran inti yaitu pelaksanaan pembelajaran sesuai dengan tema-tema yang telah ditentukan. Tema yang sudah ditentukan kemudian dirinci ke dalam sub tema dan dirincikan ke dalam su-sub tema pembelajaran. Pembelajaran inti dilakukan dari pukul 07.30-09.00 WIB. Pembelajaran inti dimulai dengan kegiatan awal yaitu dengan salam, do'a mau belajar, saling sapa dengan anak kemudian dilanjutkan dengan tanya jawab tema pembelajaran yang akan dilakukan. Kemudian 
dilanjutkan dengan kegiatan inti yaitu anak diberikan 3 tugas pilihan dalam melakukan kegiatan pembelajaran. Selanjutnya yaitu kegiatan akhir pendidik menanyakan kepada anak terkait dengan pembelajaran yang telah dilakukan selama satu hari.

4. Istirahat makan bersama

Kegiatan istirahat dilakukan pada pukul 09.00-09.30 WIB dengan kegiatan yaitu anak makan bersama dengan teman-temanya dan pendidik juga ikut makan bersama. Kegiatan makan bersama dimulai dengan berdo'a yang dipimpin oleh salah satu anak secara bergiliran dan diakhiri dengan do'a yang dipimpin oleh salah satu anak juga.

5. Kegiatan pengaman

Kegiatan pengaman adalah kegiatan yang dilakukan anak sambil menunggu penjemputan dari orang tua. Anak bermain di tempat yang sudah disetting oleh pendidik yang bertujuan untuk penjagaan anak sampai menunggu penjemputan dari orang tua.

\section{Penilaian Pembelajaran Tematik di RA Al-Muslimun}

Berdasarkan hasil pengamatan penilaian pembelajaran tematik di laksanakan di RA Al-Muslimun yaitu dengan model cek list perkembangan anak serta penugasan project dari hasil karya anak :

1. Percakapan

Dalam proses pembelajaran tematik pendidik selalu mengajak anak bercakap-cakap untuk mengetahui pemahaman anak terkait dengan pembelajaran.

2. Penugasan project

Penugasan project dilaksanakan ketika pembelajaran, pendidik memberikan tugas kepada anak dalam tiga kegiatan yang berbeda. Misal menempel, mewarnai dan kolase.

3. Hasil karya

Hasil karya adalah buah pikir anak yang dituangkan dalam bentuk karya nyata dapat berupa pekerjaan tangan, karya seni atau tampilan anak, misalnya: gambar, lukisan, lipatan, hasil kolase, hasil guntingan, tulisan/coretan-coretan, hasil roncean, bangunan balok, tari, dan hasil prakarya. Tuliskan nama dan tanggal hasil karya tersebut dibuat. Data ini diperlukan untuk 
melihat perkembangan hasil karya yang dibuat anak di waktu sebelumnya. Saat anak telah menyelesaikan karyanya, pendidik dapat menanyakan tentang hasil karya tersebut. Tuliskan semua yang dikatakan oleh anak untuk mengonfirmasi hasil karya yang dibuatnya agar tidak salah saat pendidik membuat interpretasi karya tersebut.

Pelaksanaan pembelajaran tematik di RA Al-Muslimun sudah berdasarkan prinsip-prinsip dalam pemilihan tema pembelajaran :

1. Perencanaan pembelajaran tematik

Perencanaan pembelajaran tematik dimulai dengan analisis pemilihan tema, tema yang sudah ada dianalisis dengan kompetensi dasar kemudian dituangkan ke dalam RPPM dan RPPH

2. Pelaksanaan pembelajaran tematik

a. Kedekatan Tema

Kedekatan tema yang dipilih dalam pembelajaran tematik di RA Al-Muslimun yang dekat dengan anak antara lain tema :

1) Aku hamba Allah

Tema aku hamba Allah yang di dalam nya ada sub tema tubuhku dikatakan dekat karena anak-anak yang ada di RA Al-Muslimun semua beragama Islam sehingga dengan adanya tema ini melatih anak agar dekat dengan Allah dengan cara mengetahui bahwa kita ciptaan Allah. Dipilihnya tema aku hamba juga sesuai dengan visi dan misi dari RA Al-Muslimun yaitu membentuk pribadi anak yang sholeh dan sholehah.

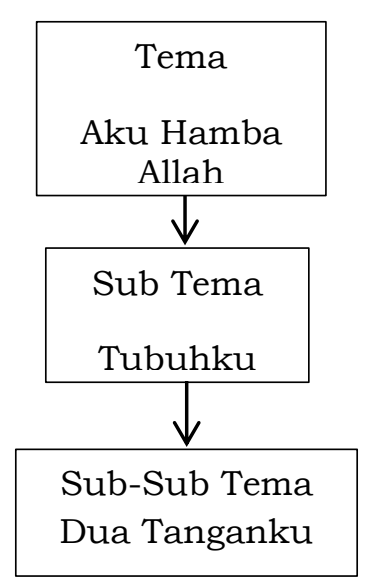

Bagan 1. Kedekatan Tema

2) Tanah airku

Tema tanah airku dikatakan dekat dengan anak-anak karena yang dikenalkan adalah negara Indonesia yang mayoritas anak-anak di RA Al Muslimun merupakan warga negara Indonesia. Selain itu tujuan dari tema ini yaitu mengenalkan kepada anak-anak tentang negara Indonesia dan apa saja yang ada di Indonesia. 


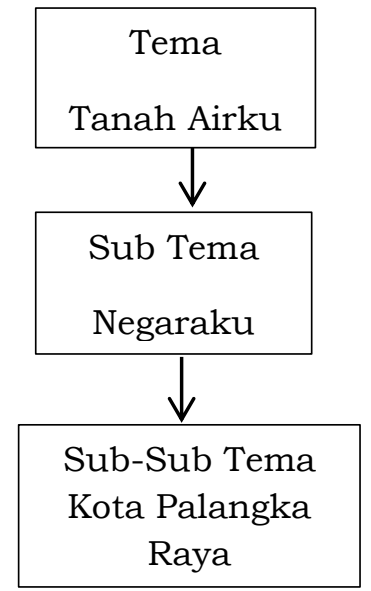

Bagan 2. Kedekatan Tema

3) Tema lingkunganku

Tema lingkunganku dikatakan dekat dengan anak karena di dalamnya ada sub tema masjidku yang secara fisik dan emosional lingkungan sekolah dekat dengan masjid sehingga dengan anak-anak dapat lebih mengenal masjid sebagai tempat ibadah.

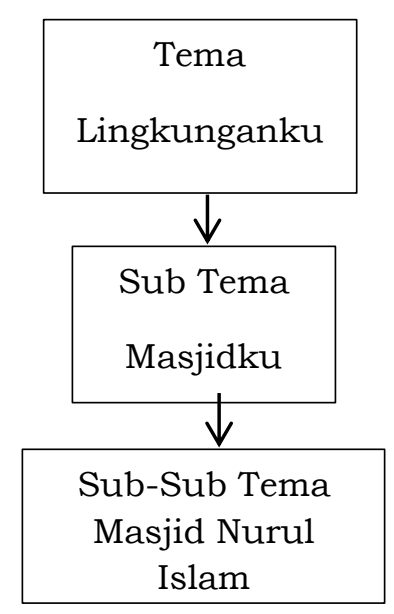

Bagan 3. Kedekatan Tema

4) Tanah amaliah Ramadhan

Amaliah Ramadhan dikatakan dekat dengan anak karena di dalam tema ini ada sub tema niat puasa dan amalan-amalan Ramadhan yang secara fisik dan emosi sub tema ini dekat dengan anak-anak karena secara umum anak-anak di RA AlMuslimun beragama Islam dan sudah mulai latihan berpuasa Ramadhan.

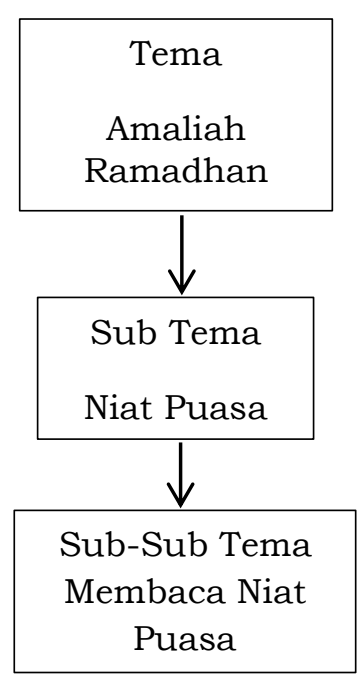

Bagan 4. Kedekatan Tema

b. Kesederhanaan Tema

Kesederhanaan tema yang digunakan dalam pembelajaran tematik di RA Al-Muslimun antara lain:

1) Tema pekerjaan dengan sub tema macam-macam pekerjaan dengan sub-sub tema berdagang.

Kebanyakan anak-anak yang sekolah di RA Al-Muslimun orang tuanya bekerja sebagai pedagang dipasar sehingga tema pekerjaan dikatakan sederhana bagi anak karena anak sudah mengenal pekerjaan berdagang. 


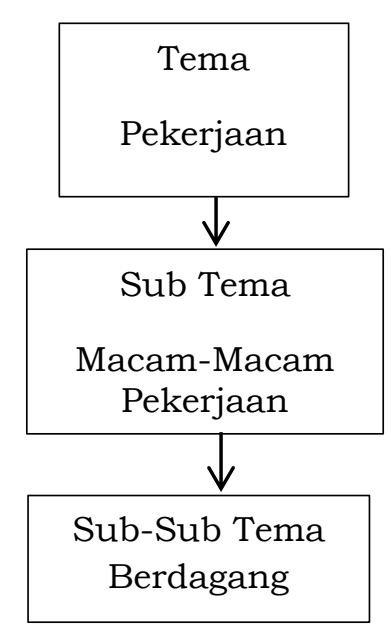

Bagan 5. Keserhanaan Tema

c. Kemenarikan Tema

Tema-tema

pembelajaran tematik yang menarik bagi anak di RA Al-Muslimun antara lain:

1) Tema Alam Semesta

Tema ini bagi anak sangat menarik karena terdapat percobaan sains sederhana yang dilakukan oleh pendidik yaitu : misal fenomena siang dan malam pendidik mendemonstrasikan siang dan malam dengan menutup kelas sehingga keadaan gelap kemudian pendidik menyalakan senter sebagai tanda matahari muncul yang menandakan bahwa terjadi perubahan malam ke siang. Bagi anak fenomena atau gejala alam seperti ini sangat menarik karena setiap hari dialami oleh anak.

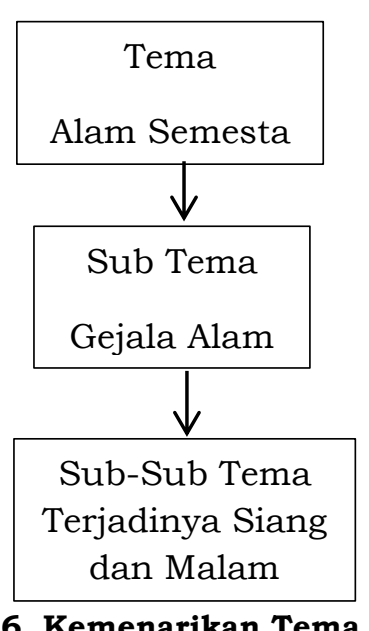

Bagan 6. Kemenarikan Tema

\section{d. Keinsidentalan Tema}

Tema insidental juga pernah dilakukan dalam proses pembelajaran tematik di RA AlMuslimun yaitu pada hari Raya Idul Adha tahun 2017, sebelum hari raya Idul Adha sub tema yang seharusnya adalah tema keluarga sakinah dengan sub tema tata tertib dalam keluarga. Karena ada peristiwa yang bermakna bagi anak sehingga sub tema binatang qurban di selipkan di dalam tema sakinah selama 1 minggu.

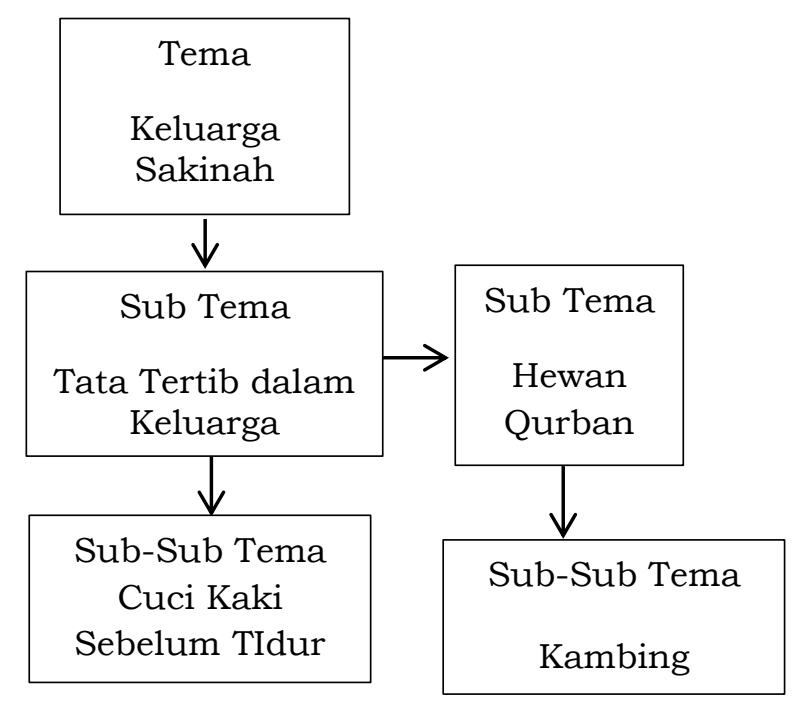


Berdasarkan analisis hasil temuan diatas dikatakan bahwa dalam pelaksanaan pembelajaran tematik di RA Al-Muslimun sesuai dengan prinsip-prinsip pembelajaran tematik yaitu meliputi tema-tema yang dipilih dekat dengan kehidupan anakanak, kesederhanan tema bagi anakanak, kemenarikan tema bagi anakanak, dan keinsidentalan tema juga sesuai dengan peristiwa yang dialami oleh anak-anak.

Keberhasilan proses pembelajaran tematik dipengaruhi oleh 3 faktor yaitu perencanaan, pelaksanan, dan penilaian. Tahapan pelaksanaan pembelajaran tematik di PAUD dimulai dengan adanya identifikasi tema yang akan digunakan dalam pembelajaran. Tema yang sudah ditentukan dianalisis dengan kemampuan dasar yang akan dikembangkan dalam proses pembelajaran. Perencanaan yang dibuat dituangkan ke dalam Rencana Pelaksanaan Pembelajaran Mingguan (RPPM) dan Rencana Pelaksanaan Pembelajaran Harian (RPPH) . Setiap RPPM mengacu dari program semester yang telah dibuat. Rencana Pelaksanaan Pembelajaran Harian (RPPH) dikembangkan secara rinci dari RPPM yang memuat tema

tertentu dari program semster. RPPH disusun berdasarkan tema/subtema atau KD yang dilaksanakan dalam satu atau lebih pertemuan.

Berdasarkan hasil wawancara dengan pendidik kelas B1 (RM), $\mathrm{RPPH}$ dibuat pendidik secara mandiri, namun sebelumnya pendidik telah menerima pelatihan serta diskusi dengan teman sejawat antar pendidik untuk penyusunan RPPH yang baik. Hasil triangulasi wawancara dengan kepala RA Al Muslimun juga menjelaskan RPPH disusun oleh pendidik itu sendiri atau disusun secara mandiri. Dalam sebuah rencana pelaksanaan pembelajaran harian dapat memuat berbagai informasi mengenai pembelajaran yang akan dilaksanakan, diantaranya kompetensi dasar, langkah kegiatan, media dan sumber belajar, indikator pencapaian pembelajaran dan hasil penilaian. pembelajaran, pendekatan/metode pembelajaran, pengelolaan dalam pelaksanaan kegiatan pembelajaran. Berdasarkan hasil penelitian didapati pendidik sudah menyusun tujuan pembelajaran yang akan dicapai, pendekatan atau metode pembelajaran yang akan digunakan sudah terdapat pada RPPH yang dibuat pendidik. 
1) Penilaian Pembelajaran Tematik

Proses penilaian pembelajaran tematik yang dilakukan di RA Al-Muslimun Kota Palangka Raya merupakan proses yang berkelanjutan dan berkesinambungan, ini bertujuan agar hasil dari informasi penilaian dapat digunakan dan bermanfaat untuk membuat alternatif-alternatif untuk mengambil keputusan (Purwanto, 1984:3). Informasi penilaian digunakan untuk melihat hasil perkembangan anak dan akan disampaikan kepada orang tua anak melalui buku penghubung yang setiap hari di catat oleh pendidik.

Tujuan

asesment perkembangan anak usia dini, antara lain untuk: (1) mendeteksi perkembangan dan arahan dalam melakukan penilaian diagnostik ketika terindikasi, yang meliputi deteksi tentang status kesehatan anak usia dini, kepekaan indera, bahasa, motorik kasar, motorik halus, dan perkembangan sosialemosional; (2) mengidentifikasi minat dan kebutuhan anak usia dini; (3) menggambarkan kemajuan perkembangan dan belajar anak usia dini; (4) mengembangkan kurikulum; (5) memperbaiki dan mengembangkan kegiatan pembelajaran yang sesuai dengan perkembangan dan kebutuhan anak usia dini; dan (6) mengasesmen program dan lembaga (akuntabilitas program dan lembaga).

Penilaian yang digunakan dalam pembelajaran tematik di RA Al-Muslimun Kota Palangka Raya yaitu dengan observasi. Observasi adalah cara pengumpulan data untuk mendapatkan informasi melalui pengamatan langsung terhadap sikap dan perilaku peserta didik, yang mengacu pada indikator yang telah di tetapkan. Aspek yang di observasi serta hasilnya bervariasi, berdasarkan pada tujuan penilaian. Obervasi dilakukan oleh pendidik pada saat proses pembelajaran.

\section{KESIMPULAN}

Berdasarkan hasil kajian teori dan pembahasan hasil penelitian maka diperoleh kesimpulan dari penelitian implementasi pembelajaran tematik di RA AlMuslimun kota Palangka Raya sebagai berikut :

1. Perencanaan pembelajaran tematik di RA Al Muslimun dimulai dengan penentuan tema yang dilakukan oleh semua pendidik diawal tahun pelajaran 
untuk menentukan tema-tema yang dipilih untuk satu tahun. Tema yang dipilih dibuat kedalam RPPM dan kemudian dituangkan ke dalam RPPH.

2. Pelaksanaan pembelajaran tematik di RA Al-Muslimun sesuai dengan prinsip-prinsip pembelajaran tematik yaitu kedekatan tema dengan kehidupan anak, kesederhanaan tema bagi anak, kemenarikan tema bagi anak, dan tema isendental dalam pembelajaran. Selain itu unuk mengakhiri setiap tema dilaksanakan kegiatan puncak tema.

3. Penilaian pembelajaran tematik di RA Al-Muslimun menggunakan penilaian percakapan, penugasan project, dan hasil karya anak.

DAFTAR PUSTAKA

Atika Sari, dkk. 2016. Pemahaman pendidik dalam Pembelajaran tematik anak usia dini. FKIP Universitas Lampung.

Dapertemen Pendidikan Nasional. 2003. Undang-Undang Sistem Pendidikan Nasional. Jakarta: Dapartemen Pendidikan Nasional Direktorat Jenderal Pendidikan Dasar Dan Menengah.

Moeleong, L. J. 2004. Metodologi penelitian kualitatif. Bandung: Remaja Rosdakarya.

Mustofa, Dedi., dkk. 2015. Pengembangan Tema Pembelajaran PAUD. Jakarta: Direktorat Jenderal PAUD dan DIKMAS.

Trianto.

2011 Desain Pengembangan Pembelajaran Tematik bagi AUD TK/RA dan Anak Kelas Awal SD/MI. Jakarta : Kencana. 